\title{
Identification of Hair Cell Progenitors and Intermitotic Migration of Their Nuclei in the Normal and Regenerating Avian Inner Ear
}

\author{
Terance T. Tsue, David L. Watling, Pedro Weisleder, ${ }^{a}$ Marc D. Coltrera, and Edwin W Rubel \\ Virginia Merrill Bloedel Hearing Research Center and Department of Otolaryngology-Head and Neck Surgery, University \\ of Washington, Seattle, Washington 98195
}

\begin{abstract}
Postembryonic production of sensory hair cells occurs in both normal and aminoglycoside-damaged avian inner ears. The cellular source and mechanism that results in new differentiated hair cells were investigated in the avian vestibular epithelia using three distinct cell-cycle-specific labeling methods to identify proliferating sensory epithelial cells. First, immunocytochemical detection of the proliferating cell nuclear antigen, an auxiliary protein of DNA polymerase, allowed labeling of cells in late $\mathrm{G} 1, \mathrm{~S}$, and early G2 phases of the cell cycle. Second, a pulse-fix tritiated thymidine autoradiographic protocol was used to identify cells in $S$ phase of the cell cycle. Finally, Hoechst 33342, a fluorescent DNA stain, was used to identify epithelial cells in mitosis.

The distribution of cells active in the cell cycle within the normal and ototoxin-damaged vestibular epithelium suggests that supporting cells within the sensory epithelia are the cellular precursors to the regenerated hair cells. Differences between the proliferation marker densities in control and damaged end organs indicate that the upregulation of mitotic activity observed after streptomycin treatment is due primarily to an increase in the number of dividing progenitor cells. The differences between the extent of ototoxic damage and the level of reparative proliferative response suggest a generalized stimulus, such as a soluble chemical factor, plays a role in initiating regeneration. Finally, after DNA replication is initiated, progenitor cell nuclei migrate from their original location close to the basement membrane to the lumenal surface, where cell division occurs. This pattern of intermitotic nuclear migration is analogous to that observed in the developing inner ear and neural epithelium.

IKey words: proliferating cell nuclear antigen (PCNA), vestibular system, hair cell regeneration, cell cycle, tritiated thymidine, bisbenzimide, intermitotic nuclear migration]
\end{abstract}

Postembryonic production of hair cells has been demonstrated in elasmobranchs (Corwin, 1981, 1983), fish (Popper and Hoxter, 1984, 1990; Presson and Popper, 1990), and amphibians

\footnotetext{
Received Jan. 22, 1993; revised June 25, 1993; accepted June 29, 1993.

We greatly appreciate Drs. Edward Lachica and Elizabeth Oesterle for their helpful suggestions in the preparation of this manuscript. We thank Jialin Shang, Jonathan Matsui, Glen MacDonald, and Dale Cunningham for their outstanding technical assistance, and Janet Clardy and Paul Schwarz for their expert photographic assistance. This work was supported by NIH Grants NS09256, DC00018, DC00035, and DC00395, and the Deafness Research Foundation.

Correspondence should be addressed to Edwin W Rubel, Ph.D., Virginia Merrill Bloedel Hearing Research Center, University of Washington School of Medicine RL-30, Seattle, Washington 98195

aPresent address: Department of Zoology, University of Texas, Austin, TX 78712

Copyright $(\mathcal{C} 1994$ Society for Neuroscience $0270-6474 / 94 / 140140-13 \$ 05.00 / 0$
}

(Corwin, 1985). In both birds and mammals, it was believed that the capacity to produce inner ear hair cells was lost early in the postnatal period (Ruben, 1967). In 1988, Jørgensen and Mathiesen were the first investigators to demonstrate continuous production of hair cells in the mature avian vestibular system. Roberson et al. (1992) observed a similar low level of ongoing proliferation in the postnatal chick vestibular epithelium. Thus far, significant levels of normal postembryonic hair cell production in the avian auditory system have not been demonstrated despite evidence for a very low rate of ongoing supporting cell proliferation (Ryals and Westbrook, 1990; Oesterle and Rubel, 1993). Contrastingly, several studies of the avian basilar papilla have demonstrated the morphologic regeneration of sensory epithelia following acoustic or ototoxic damage (Cotanche, 1987; Cruz et al., 1987; Corwin and Cotanche, 1988; Ryals and Rubel, 1988). A concomitant physiologic recovery of function also occurs (McFadden and Saunders, 1989; Tucci and Rubel, 1990). Recently, our laboratory has documented a similar process of hair cell regeneration in the avian vestibular system following aminoglycoside insult (Weisleder and Rubel, 1992, 1993). Given the similarities between the bird and mammal vestibular system (Retzius, 1884; Ramprashad et al., 1986), and the common developmental origins of the auditory and vestibular systems, understanding how sensory regeneration takes place in the vestibular system of birds may provide clues for eliciting regeneration in the mammalian inner ear.

The cellular source of new postembryonic hair cells may be different in different systems. New hair cells in the axolotl lateral line are believed to originate from supporting cell progeny (Balak et al., 1990). In the fish statoacoustic end organ there is evidence for an embryonic-like neuroepithelial cell precursor (Presson and Popper, 1990). Hair cells in different regions of the chick basilar papilla may arise from either organ supporting cells or hyaline cells (Girod et al., 1989; Duckert and Rubel, 1990, 1993; Raphael, 1992). In the normal chick vestibular system, Roberson et al. (1992) described a statistically significant pairwise association between autoradiographically labeled supporting cells and hair cells. Further work in our laboratory by Weisleder and Rubel (1993) demonstrated autoradiographic labeling of supporting cells in the chick vestibular sensory epithelium as early as $1 \mathrm{~d}$ after aminoglycoside damage. These results suggest that one or more types of organ supporting cells are the progenitor of ncw hair cells in the avian vestibular epithelium.

Identifying the cellular source and the cascade of events leading to a new differentiated hair cell is integral to elucidating, and possibly controlling, the trigger mechanism initiating vestibular epithelial regeneration. In the present study, we used 


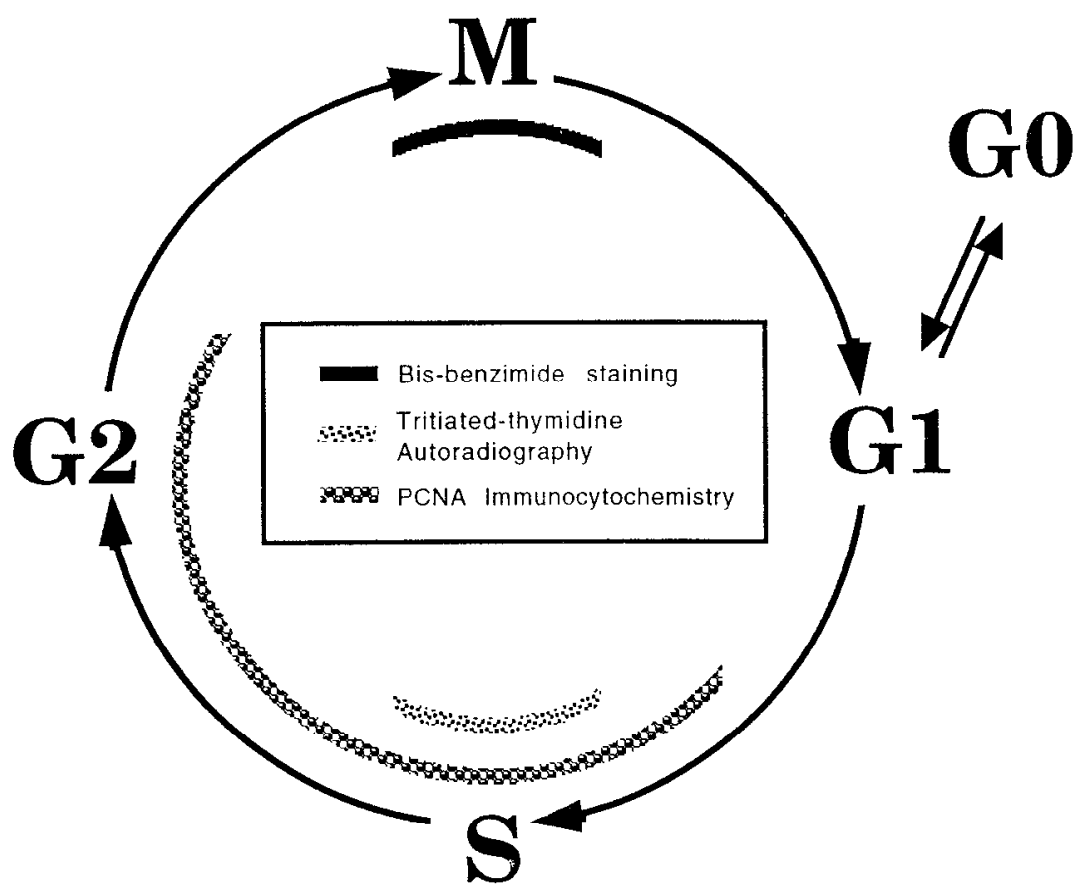

Figure 1. A simplified schematic of the cell cycle showing the cell-cycle phases detected by the three labeling methods used in this study. GO phase represents a nonproliferating or quiescent state. G1 phase is the cellular preparatory state for the DNA replication phase or $S$ phase. $G 2$ phase is the cellular preparatory state for mitosis or $M$ phase.

three distinct labeling methods to identify and locate proliferating cells (Fig. 1). First, the immunocytochemical (ICC) detection of the proliferating cell nuclear antigen (PCNA), a $36 \mathrm{kDa}$ auxiliary protein of DNA polymerase- $\delta$, allowed labeling of the enzyme complex responsible for leading-strand synthesis during DNA replication (Celis et al., 1987; Prelich et al., 1987; Prelich and Stillman, 1988; Lee and Hurwitz, 1990). PCNA is tightly associated with DNA replication sites in the cell nucleus and is found at peak levels during the "synthesis," or S phase of the cell cycle, with moderate immunodetectable levels present in late G1 and early G2 phases of the cell cycle as well (Kurki et al., 1986; Bravo and Macdonald-Bravo, 1987; Ogata et al., 1987; Raska et al., 1989; Bruno et al., 1991). Second, classical autoradiographic (AR) techniques were used to label dividing cells that had incorporated and retained tritiated thymidine ( ${ }^{3} \mathrm{H}$-thymidine) in their replicating DNA during S phase of the cell cycle. Finally, staining the minor groove of DNA with the fluorescent nucleic acid stain Hoechst 33342 (bisbenzimide) allowed visualization of chromosomal structure (Shapiro, 1989). This provided easy identification of cells with condensed chromatin in mitosis (M phase of cell cycle).

Using these labeling techniques, the proliferating cells in the epithelium can be identified and their epithelial distribution followed throughout a majority of the cell cycle. The results support the hypothesis that supporting cells in the sensory epithelium give rise to new hair cells in all end-organ types in both the normal and regenerating chick vestibular system. Differences between the proliferation marker densities in control and damaged end organs indicate that the upregulated proliferative state observed after sensory epithelial damage is due primarily to an increase in the numbers of dividing precursor cells. Mismatch between the extent of ototoxic damage and the level of reparative proliferative response suggests that a generalized stimulus, such as a soluble chemical factor, plays a role in initiating regeneration. In addition, the distribution of labeled $S, G 2$, and $M$ phase cells within the sensory epithelium demonstrates that nuclei of the proliferating precursor supporting cells migrate from the basal to lumenal epithelial surface prior to mitosis and to production of new hair cells and supporting cells.

\section{Materials and Methods}

White Leghorn chickens (Gallus domesticus) were incubated and hatched at $37^{\circ} \mathrm{C}$ from fertilized eggs obtained from a local supplier $(\mathrm{H}$ and $\mathrm{N}$ International, Redmond, WA). The chicks were grown for 10-14 d after hatching prior to experimental use. Animals were divided into two groups; the experimental group birds were given daily intramuscular injections of streptomycin sulfate $(1200 \mathrm{mg} / \mathrm{kg}$; Sigma Chemical Co., St. Louis, MO) for 5 consecutive days, while the age-matched control group birds received no injections. In chicks, sham intramuscular injections with drug vehicle have been shown not to cause inner ear hair cell damage (Lippe et al., 1991). All experimental protocols were approved by the University of Washington Animal Care Committee. Approximately 75 chicks were used to develop final protocols and to obtain qualitative information on location and numbers of cells expressing the cell-cycle markers employed. The sample sizes noted below refer to the numbers of animals and organs from which quantitative data were obtained.

PCNA immunocytochemistry. Three birds received streptomycin treatment and three control birds received no injections. One day after the last streptomycin injection, all animals were deeply anesthetized with intraperitoneal pentobarbital sodium (Abbott Laboratories, North Chicago, IL) and underwent bilateral intralabyrinthine perfusion via the oval window and the surgically exposed lateral semicircular canal with methanol-Carnoy's fixative. After decapitation, the utricle, saccule, posterior and superior ampullae, and lagena were dissected free from both ears. The lateral ampulla was discarded, since it was routinely damaged during intralabyrinthine perfusion. A small section of proximal bowel was removed from a normal bird to serve as a positive immunocytochemical control. The vestibular organs were then immersed in methanol-Carnoy's fixative overnight $\left(4^{\circ} \mathrm{C}\right)$. Vestibular organs were rehydrated in a descending gradient of ethanol and immersed in phosphatebuffered saline (PBS; pH 7.4) containing a dilute eosin solution to assist in organ visualization during paraffin embedding. End organs were placed into molds containing a $1 \%$ SeaKem LE agarose (FMC, Rockland, ME) in PBS solution that had been cooled from boiling to $50^{\circ} \mathrm{C}$. Maculae (utricle, saccule, and lagena) were oriented to allow sectioning in a plane perpendicular to the otoconial membrane. The ampullae were oriented to allow sectioning in a plane parallel to the septum cruciatum. Each agarose block held up to four vestibular organs. The agarose blocks were hardened on ice, trimmed, dehydrated in an ascending series of ethanol, cleared in xylene, and paraffin embedded. The tissue was serially sec- 
lioned ( $5 \mu \mathrm{m}$ ) and mounted at $25 \mu \mathrm{m}$ intervals onto acid-washed chromealum-subbed glass slides. All processing and mounting temperatures were kept below $55^{\circ} \mathrm{C}$.

PCNA immunocytochemistry (ICC) was performed on all mounted sections using the murine anti-PCNA IgM monoclonal antibody 19A2 (Coulter Immunology, Hialeah, FL) as previously described (Garcia et al., 1989). After deparaffinization in Histo-Clear (National Diagnostics, Manville, NJ) and rehydration in a graded ethanol series, endogenous peroxidase activity was blocked using $0.3 \%$ hydrogen peroxide with sodium azide. After buffer washes, the 19A2 monoclonal antibody (Ogata et al., 1987), diluted 1:1000, was laid on tissue sections overnight $\left(4^{\circ} \mathrm{C}\right)$. A dilution of 1:8000 was used for the bowel tissue positive control. Normal mouse serum served as negative immunocytochemical control for the primary antibody. After further washes, the biotinylated antimouse IgG secondary antibody (Vector Laboratories, Inc., Burlingame, CA) was applied at a 1:1000 dilution for $45 \mathrm{~min}$ (room temperature). Subsequently, the tissue was incubated in a 1:5000 dilution of peroxidase-conjugated streptavidin (Jackson ImmunoResearch Laboratories, Inc., West Grove, PA) for $30 \mathrm{~min}$ (room temperature). The sections were developed using 3, $3^{\prime}$-diaminobenzidine in $0.05 \mathrm{~m}$ Tris buffer $\left(37^{\circ} \mathrm{C}\right.$; $\mathrm{pH} 8.0$ ) with nickel chloride color enhancement. The tissue was lightly counterstained with methyl green, dehydrated, and coverslipped with Histomount (National Diagnostics, Manville, NJ).

Tritiated thymidine DNA autoradiography. Four chicks were treated with streptomycin and two age-matched control birds received no injections. One day after treatment, all chicks were given a single $20 \mu \mathrm{Ci} /$ gm body weight intramuscular injection of [methyl- $\left.{ }^{3} \mathrm{H}\right]$-thymidine $(81$ $\mathrm{Ci} / \mathrm{mmol}, 1.0 \mathrm{mCi} / \mathrm{ml}$; New England Nuclear Research Products, Wilmington, DE). After 1 or 3 hr postinjection, the birds were deeply anesthetized and the vestibular organs were perfused, dissected free, and immersion fixed in 3.5\% glutaraldehyde in PBS. The end organs were postfixed in osmium $\left(1 \% \mathrm{OsO}_{4}\right.$ in $\left.\mathrm{PBS}\right)$ for $1 \mathrm{hr}$, dehydrated in a graded ethanol series and propylene oxide, and embedded in Spurr's resin (Polysciences, Warrington, PA). Serial semithin sections $(3 \mu \mathrm{m})$ were cut through half of the organ with a diamond knife and mounted onto acid-washed chrome-alum-subbed slides. The slides were dipped in Kodak NTB-2 Nuclear Track emulsion (diluted 1:1 with distilled water) and stored at $4^{\circ} \mathrm{C}$ for 15 weeks. The slides were developed in Kodak D-19 developer and Kodak Fixer before counterstaining lightly with dilute toluidine blue and coverslipping.

Fluorescent nucleic acid staining. Two birds were treated with aminoglycoside and two control birds received no injections. Two days after the last injection, the birds were deeply anesthetized and underwent bilateral perfusion of their vestibular labyrinths with $4 \%$ paraformaldehyde. The utricle and saccule were dissected from each ear and immersion fixed overnight. After PBS washes, the otoconial mass was removed from each end organ under a dissecting microscope. The tissue was immersed in Hoechst $33342(20 \mu \mathrm{g} / \mathrm{ml}$; Sigma Chemical Company, St. Louis, MO) in the dark for $1 \mathrm{hr}$. The organs were washed in PBS and placed on glass slides as whole-mounts using Vectashield (Vector Laboratories, Burlingame, CA).

Data analysis. Autoradiographic (AR) sections $12 \mu \mathrm{m}$ apart (one in four) and PCNA ICC sections $25 \mu \mathrm{m}$ apart (one in five) were analyzed using standard light microscopy for the presence of labeled nuclei in the sensory epithelium. The sensory epithelium was artificially bisected into basal (BL) and lumenal (LL) layers (Fig. 2). The BL consisted of all cell nuclei within two nuclear diameters (approximately $13 \mu \mathrm{m}$ ) of the basement membrane. The LL was comprised of the remaining lumenal one-half to two-thirds of the epithelial thickness. In the normal vestibular epithelia, the $\mathrm{BL}$ contains supporting cell nuclei while hair cell nuclei and a small percentage of supporting cell nuclei are found in the LL.

For each section, the layer location of each labeled nucleus in the epithelium was recorded. In addition, the length of the sensory epithelium was measured along the basement membrane using Image 1.45 (Research Services Branch, NIMH, Bethesda, MD). This allowed determination of the labeled nucleus linear density (number of labeled nuclei per millimeter of sensory epithelium) for both the BL and LL. Total linear density of labeled nuclei equaled the sum of BL and LL density values. For each end organ, mean density values were calculated for the region sectioned. Values for percentage of label in a given layer, $\mathrm{BL}$ or $\mathrm{LL}$, were calculated from the ratio of the label density in that layer to total label density (i.e., percentage of total label in $\mathrm{BL}=$ density in $\mathrm{BL} /$ total label density). The cell type (hair cell or supporting cell) of each labeled nucleus was identified in the plastic-embedded AR sections.
Because of the histological limitations of alcohol fixation and agaroseparaffin embedding, exact cell-type characterization in the PCNA ICC sections was not possible, and cells were identified by nuclear location only.

Whole-mount maculae stained with bisbenzimide were visualized using an epifluorescence microscope with ultraviolet exciter filter. The whole epithelial surface area was examined and the locations of mitotic figures (prophase through telophase) were noted with reference to focal plane in the sensory epithelium.

For statistical analysis, the mean linear density of labeled nuclei for the BL and LI for each organ in each animal served as individual observations. This score consisted of the average linear density computed from 5 to 45 sections ( 5 to 27 for each crista ampulla and 6 to 45 for each macula). These values were then subjected to an ANOVA using superanova (Abacus Concepts, Inc., Berkeley, CA). Post hoc individual comparisons, where appropriate, used the Student-NewmanKeuls method (superanova). For density scores generated from PCNAimmunostained tissue, a two-way ANOVA model was used comparing treatment (ototoxin-treated vs control) and epithelial layer (BL vs LL) for each end-organ type (utricle, saccule, lagena, and ampulla). For tissue treated with ${ }^{3} \mathrm{H}$-thymidine, a three-way ANOVA model was used, adding survival time ( $1 \mathrm{hr}$ vs $3 \mathrm{hr}$ ) as the third parameter. Additional analyses were used to compare the labeling density across organs.

\section{Results}

Normal and aminoglycoside-damaged vestibular anatomy

The avian vestibular labyrinth contains two types of sensory organs: the crista ampullaris and the macula. The three orthogonal ampullary organs (lateral, superior, and posterior) detect angular acceleration and the three otolithic organs (utricle, saccule, and lagena) detect gravitational and linear accelerations. The end-organ shapes are heterogeneous, but the basic cellular composition of the sensory epithelium is identical in all the organs. The sensory epithelium contains both sensory hair cells and nonsensory supporting cells (Fig. 2). Two types of hair cells can be differentiated on the basis of their morphology and innervation (Wersäll, 1956; Jørgensen and Christensen, 1989). Type I hair cells are pear-shaped and enclosed in a nerve calyx that surrounds all but the most apical portion of the cell. More than one hair cell can be enclosed in a single nerve calyx. Type II hair cells arc cylindrical in shape and have multiple boutontype nerve endings at the basal portion of the cell. No morphologic distinctions could be made within the nonsensory cell population of the sensory epithelium at the light microscopic level, and all are currently defined as supporting cells. Supporting cells mostly inhabit the basal layers of the sensory epithelium, resting on the basement membrane. They have a cuboidal morphology and many extend to the lumenal surface, enveloping the sensory hair cells (Corwin et al., 1991). Because of the contorted and irregular lumenal extension of the supporting cells, serial ultrastructural studies would be required to determine which supporting cells did or did not extend to the lumenal surface, as has been observed in the amphibian (Jørgensen, 1981).

One day after the last aminoglycoside injection, tissue from the streptomycin-treated end organs shows signs of severe damage (Fig. $2 B$ ). Type I hair cells are absent and type II hair cells are reduced in number compared to controls. Using a similar streptomycin-treatment paradigm, Weisleder and Rubel (1993) demonstrated that control chick ampullae have almost six times more hair cells than treated ampullae $(p<0.0001)$. The supporting cell layer appears unaffected. Compared to control tissue, the distribution of nuclei in the damaged epithelium is more heterogeneous and less polarized into the classical basal supporting cell layer and more lumenal hair cell layer. These results are comparable to those observed previously in the chick am- 

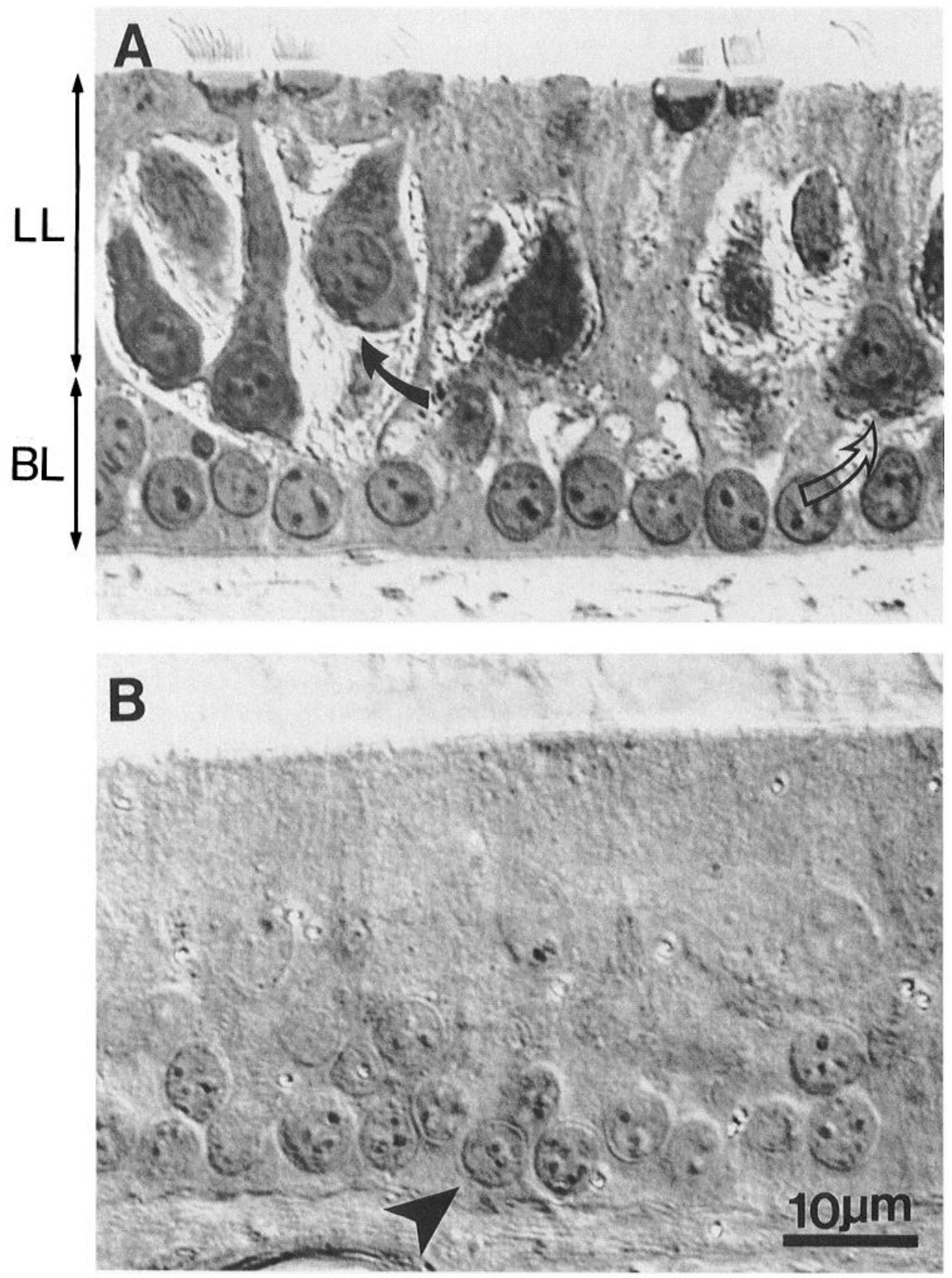

Figure 2. Photomicrographs of the normal $(A)$ and streptomycin-damaged $(B)$ utricular sensory epithelium from a 13-d-old chick. The solid arrow points to a pear-shaped type I hair cell, while the open arrow points to a cylindershaped type II hair cell. The arrowhead shows supporting cells along the basement membrane. Note the decreased number of hair cells and increased layering of supporting cells in the damaged tissue. Nuclear epithelial location is defined as being in the BL or LL. pulla and utricle (Weisleder and Rubel, 1992, 1993) and in mammals (Wersäll and Hawkins, 1962; Duvall and Wersäll, 1964).

\section{PCNA ICC}

Sensory epithelial immunolabel was isolated to the cell nucleus and easily recognized as distinct homogeneously distributed black spots (Fig. 3). Immunolabeled nuclei tended to be of larger diameter and to have a more rounded morphology compared to unlabeled cells in the same epithelial layer. In two control saccules, the mean nuclear area $( \pm$ SD) of 10 randomly chosen PCNA-immunolabeled supporting cells was $22.5( \pm 5.3) \mu \mathrm{m}^{2}$ compared to $16.1( \pm 4.0) \mu \mathrm{m}^{2}$ for neighboring (three adjacent on each side) unlabeled supporting cell nuclei $(n=60)$. Similarly, in two damaged saccules, the mean nuclear area of immuno- labeled nuclei $(n=10)$ was $21.6( \pm 4.5) \mu \mathrm{m}^{2}$ versus only 14.1 $( \pm 2.4) \mu \mathrm{m}^{2}$ for unlabeled nuclei $(n=60)$. These differences in mean nuclear area between PCNA-immunolabeled and unlabeled nuclei were statistically significant $(p<0.001)$. Most labeled cells were found as singles or pairs in both control and damaged vestibular end organs, but small cell clusters were also observed in some damaged tissue. Mesenchymal labeling of endothelial cells, glial cells, and fibroblasts was also observed in the inner ear tissue. In the positive control tissue, PCNA ICC showed specific nuclear labeling in the proliferating cells of the intestinal crypt with decreasing label as the villous tip was approached. The mouse serum negative control showed no appreciable background.

Normal maculae and ampullae had an even distribution of label across the sensory epithelium. More specifically, no to- 

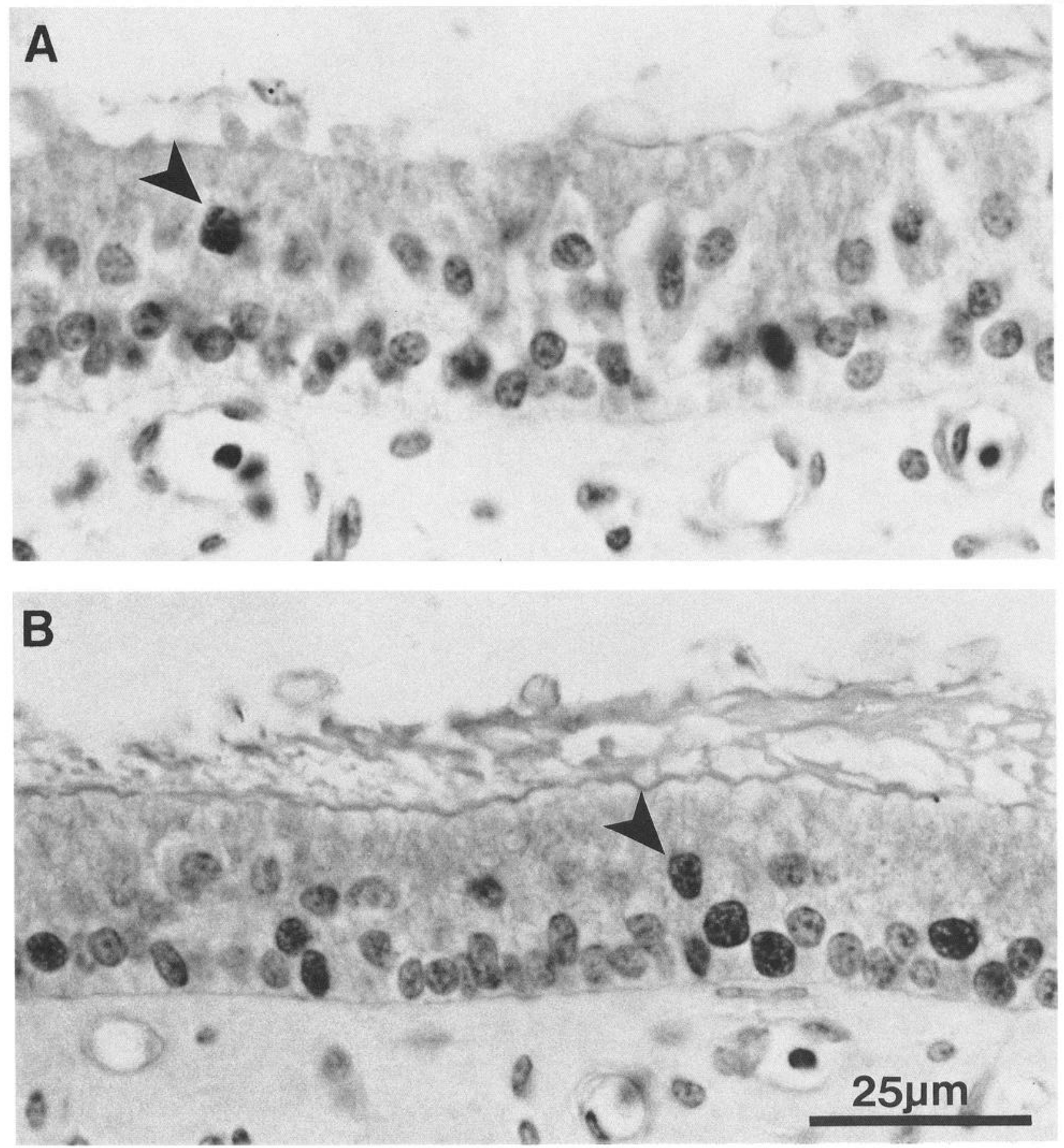

Figure 3. ICC labeling of the PCNA in nuclei of proliferating vestibular sensory epithelial cells. PCNA immunolabel is observed in both the normal $(A)$ and streptomycin-damaged $(B)$ utricle. The arrowheads point to the characteristic nuclear stippling pattern of the immunolabel.

pographical predisposition to the peripheral or central neuroepithelial zones was observed. In the aminoglycoside-damaged organs, a similar distribution was observed, except for a modest predilection for increased numbers of labeled nuclei in zones where there was less damage or no detectable damage, that is, regions where a normal complement of hair cells remained. This was consistently observed across all end-organ types. Also, a gradient of decreased label density was observed in control and damaged lagenar tissue as the auditory epithelium was approached. In both control and drug-treated ampullae, epithelial labeling density decreased as the septum cruciatum was ap- proached. Some dark cells, a nonsensory epithelial cell with dark staining characteristics located at the extreme skirts of the crista ampulla, were labeled as well.

\section{Transepithelial distribution of PCNA immunolabel}

A summary of the results is given in Table 1. This table shows the mean labeled nuclei linear density in the BL, LL, and total epithelium for both control and damaged end organs.

In all four vestibular end-organ types of the control animals, the label density was greater in the BL than the LL (Fig. 4). The percentage of labeled nuclei in the BL ranged from $72 \%$ in the 
Table 1. Mean PCNA immunolabel linear density in the maculae and ampullae of control and streptomycin-damaged birds

\begin{tabular}{|c|c|c|c|c|c|c|c|c|c|c|c|c|}
\hline & \multicolumn{3}{|c|}{$\begin{array}{l}\text { Utricle } \\
(n=6 / 6)\end{array}$} & \multicolumn{3}{|c|}{$\begin{array}{l}\text { Saccule } \\
(n=6 / 6)\end{array}$} & \multicolumn{3}{|c|}{$\begin{array}{l}\text { Lagena } \\
(n=2 / 6)\end{array}$} & \multicolumn{3}{|c|}{$\begin{array}{l}\text { Ampulla } \\
(n=5 / 10)\end{array}$} \\
\hline & BL & LL & $\mathrm{T}$ & BL & LL & $\mathrm{T}$ & $\mathrm{BL}$ & LL & $\mathrm{T}$ & BL & LL & $\mathrm{T}$ \\
\hline \multirow[t]{2}{*}{$\mathrm{C}$} & 0.36 & 0.14 & 0.51 & 0.34 & 0.11 & 0.44 & 1.1 & 0.14 & 1.2 & 0.84 & 0 & 0.84 \\
\hline & $(0.11)$ & $(0.05)$ & $(0.16)$ & $(0.14)$ & $(0.05)$ & $(0.18)$ & $(0.21)$ & $(0.01)$ & $(0.2)$ & $(0.27)$ & $(0)$ & $(0.27)$ \\
\hline \multirow[t]{2}{*}{ D } & 4.7 & 2.2 & 6.8 & 18 & 5.4 & 23 & 2.6 & 0.61 & 3.2 & 2.0 & 0.78 & 2.8 \\
\hline & $(0.52)$ & $(0.34)$ & $(0.82)$ & $(2.7)$ & $(0.54)$ & $(2.6)$ & $(0.59)$ & $(0.12)$ & $(0.65)$ & $(0.45)$ & $(0.21)$ & $(0.58)$ \\
\hline UR & & & $13 \times$ & & & $52 \times$ & & & $2.7 \times$ & & & $3.3 \times$ \\
\hline
\end{tabular}

PCNA immunolabel linear density was determined by counting the labeled nuclei in the basal (BL) and lumenal (LL) layers of the sensory epithelium and dividing by the length of sensory epithelium $(\mathrm{mm})$ analyzed. Total (T) linear density values are equal to the sum of the BL and LL density components. Mean values for each vestibular end-organ type are given (SEM). Control (C) organ densities are compared to streptomycin-damaged (D) organ densities revealing a profound upregulation (UR) in total linear density in all organ types. " $n$ " refers to number of control/damaged organs analyzed to obtain mean density values.

utricle to $100 \%$ in the ampulla, with the saccule and lagena having intermediate values. The normal lagena had the highest density of labeled nuclei, followed by the ampulla, utricle, and saccule.

Overall, a large increase in label density compared to control values was observed in the streptomycin-treated tissue. This profound upregulation is most evident in the saccule $(52 \times)$. The lagena and ampulla had the least increase in label density, while the utricle had an intermediate response. As was evident in control tissue, label density was greatest in the BL. The percentage of total labeled nuclei in the BL was $68 \%$ in the utricle, $77 \%$ in the saccule, and $81 \%$ in the lagena. These percentages were similar to those observed in control otolithic organ tissues. Contrastingly, the streptomycin-damaged ampullary organ had $72 \%$ of labeled nuclei in the BL, compared to the $100 \%$ in control tissue. Unlike in the control organs, the damaged saccule had the highest total linear density of proliferating cells, followed by the utricle, lagena, and ampulla.

Statistical comparison of immunolabel density in the two epithelial layers was highly significant in the control utricle, saccule, and ampulla $(p<0.01)$ and significant in the control lagena $(p=0.02)$. Similarly, the increase in label density after streptomycin treatment observed in all end-organ types was highly significant $(p<0.01)$. Comparisons of label density between control end-organ types did not yield significant differences. However, in tissue from aminoglycoside-treated animals, the saccule showed reliably more labeling than the other end organs $(p<0.05)$, supporting the conclusion that the saccule demonstrated the greatest amount of proliferative upregulation. Further support for this conclusion is provided by a highly reliable interaction between organ type and treatment paradigm when total label density was analyzed by a two-way ANOVA $(p<0.001)$.

\section{Tritiated thymidine autoradiography}

Cells that had entered the cell cycle and undergone DNA synthesis (S phase) within the 1 or $3 \mathrm{hr}$ time periods of exposure to ${ }^{3} \mathrm{H}$-thymidine were identified by the presence of five or more silver grains over their nuclei. In both control and aminoglycoside-damaged tissue, labeled cells generally had in excess of 15 silver grains overlying the nucleus and were similar in shape and size to adjacent unlabeled nuclei. Labeled stromal cells consisted of endothelial cells, glial cells, and fibroblasts. The majority of label was found in supporting cells of the sensory epithelium (Fig. 5). In both control and damaged tissue, the labeled nuclei of these supporting cells were evident at all levels from the basement membrane to the lumenal surface. No labeled hair cells were observed with these short pulse-fix procedures.

As with PCNA, ${ }^{3} \mathrm{H}$-thymidine-labeled cells were found in singles, pairs, and, rarely, as small clusters in damaged organs. An even distribution of AR label was observed across the end organ in control otolithic and ampullary tissue, but tissue from ototoxin-treated animals again showed a slight predilection for label in the less damaged and undamaged zones. Similar label distribution patterns across the end organs were observed in the 1 and $3 \mathrm{hr}$ survival groups, with the only difference being in the number of labeled cells. In the $3 \mathrm{hr}$ survival group there was an average $36 \%$ increase in label density over that in the $1 \mathrm{hr}$ survival group.

\section{Transepithelial distribution of tritiated thymidine label}

A summary of the results obtained after $1 \mathrm{hr}$ and $3 \mathrm{hr}{ }^{3} \mathrm{H}$ thymidine survival periods is shown in Table 2 . After only 1

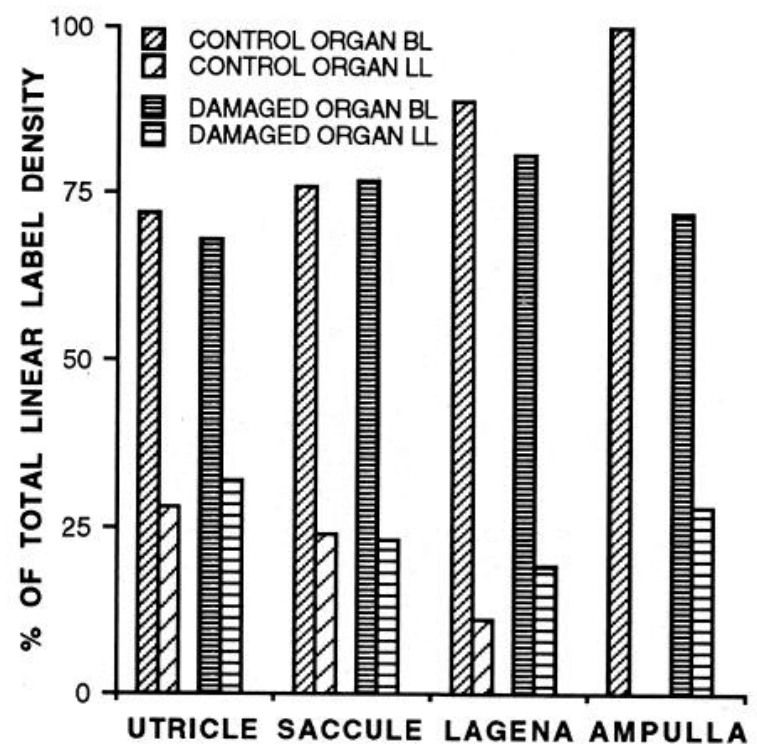

Figure 4. Percentage of total PCNA immunolabel linear density in the BL and LL of the vestibular sensory epithelium. Results for both normal and streptomycin-damaged tissue are shown for all end-organ types. 

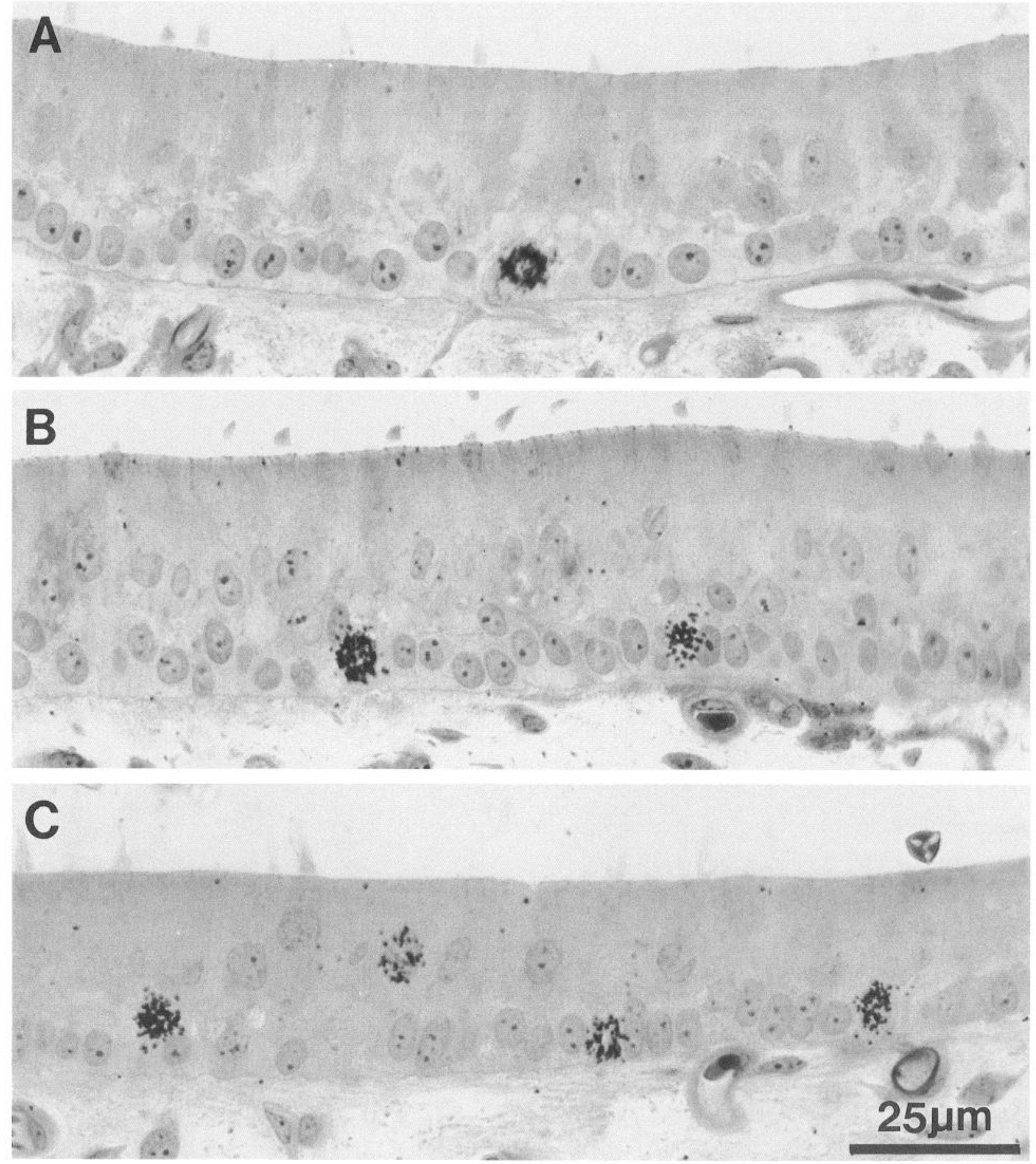

Figure 5. Tritiated thymidine AR labeling of proliferating cells in the vestibular sensory epithelium. $A$, Tritiated thymidine label in the normal saccule $1 \mathrm{hr}$ after radioactive marker injection. $B$ and $C$, Tritiated thymidine label is seen in increased density in streptomycin-damaged saccules $1 \mathrm{hr}(B)$ and $3 \mathrm{hr}(C)$ after radioactive marker injection.

hr of exposure to ${ }^{3} \mathrm{H}$-thymidine, both control and streptomycindamaged organs have labeled cells in their sensory epithelium. At least $95 \%$ of labeled cells are found in the BL in all control end-organ types (Fig. 6). Streptomycin-treated vestibular organs showed at least a $2.9 \times$ increase in label density compared to controls, with at least $93 \%$ of label located in the BL.

In animals killed $3 \mathrm{hr}$ after ${ }^{3} \mathrm{H}$-thymidine injection, label density was increased compared to $1 \mathrm{hr}$ values in all normal and damaged organs with the exception of the drug-treated ampulla.
BL label was again more predominant in both control and damaged tissue, but to a lesser degree than observed at $1 \mathrm{hr}$ after radioactive marker injection. In controls, BL label accounted for only $77-93 \%$ of total label density. Damaged tissue again revealed at least a $1.9 \times$ increase in mean total label density compared to controls, with only $70-90 \%$ of this label being observed in the BL.

Statistical comparisons of ${ }^{3} \mathrm{H}$-thymidine label density between the two epithelial layers revealed a highly significant dif- 
Table 2. Mean autoradiographic-label linear density in control and streptomycin-damaged vestibular organs 1 and 3 hr after tritiated thymidine injection

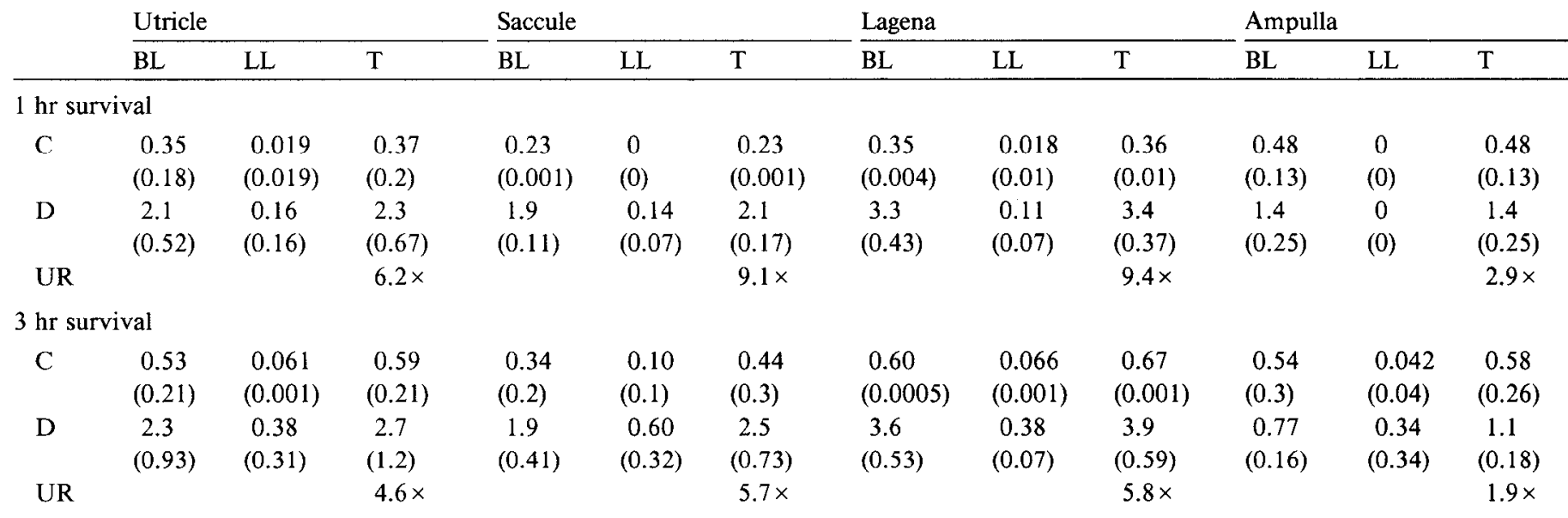

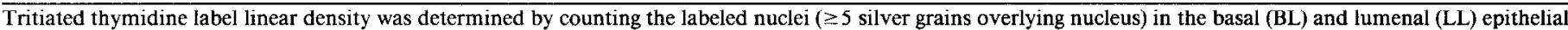

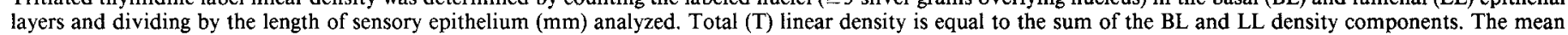

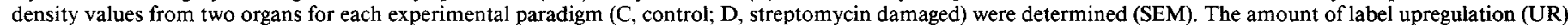
after aminoglycoside damage is shown for each organ type and survival period.

ference in each end-organ type and in each survival period ( $p$ $<0.01)$. The increase in total label density after streptomycin treatment was highly significant in the maculae $(p<0.01)$ and significant in the ampullae $(p<0.05)$ for both survival periods.

\section{Fluorescent nucleic acid staining}

Using bisbenzimide, the nuclear DNA of all epithelial cells in the maculae could be visualized under epifluorescence. Finefocusing allowed different cellular layers of the sensory epithelium to be visualized independently in the whole-mount preparations. The densely packed supporting cell nuclear layer was observed basally in the epithelium (Fig. $7 \mathrm{~A}$ ). The sparsely packed hair cell nuclei were observed more lumenally in the epithelium (Fig. $7 B$ ). Interphase cells had a baseline light fluorescence homogeneously distributed throughout the nuclear area. The condensed chromatin of prophase, metaphase, anaphase, and telophase mitotic figures were much higher in fluorescent intensity and of characteristic shape, occupying only part of the nuclear area (Fig. $7 C, D$ ). Out of the 42 and 111 mitotic figures observed in the control and drug-treated maculae, respectively, $100 \%$ of them were positioned in a focal plane at or more lumenal than the layer of hair cell nuclei ( $\leq 19 \mu \mathrm{m}$ of the lumenal surface; Figs. 7,8 ). They were located throughout the epithelial surface area. The spindle axis appeared to be tangential and the cellular cleavage plane perpendicular to the lumenal surface. This pattern was consistently observed in both utricles and saccules.

\section{Discussion}

The ability of the avian inner ear to repair itself after pharmacologic or mechanical epithelial injury has raised hopes of someday being able to reproduce this process in humans. Determining the progenitor source and the cascade of events leading to a new inner ear hair cell is integral to understanding the signals initiating and regulating this regeneration process. The present study used three distinct labeling techniques to identify proliferating sensory epithelial cells in different phases of the cell cycle. During analysis of labeling data, two technical points about PCNA and ${ }^{3} \mathrm{H}$-thymidine labeling became evident that were important in interpreting the quantitative results. First, the PCNA immunolabel was observed to be useful as a peri-S phase-specific marker in the chick inner ear. Second, short survival periods after injection of ${ }^{3} \mathrm{H}$-thymidine allowed only proliferating cells to be labeled, not their progeny. These technical considerations and the distribution of the three labels in the sensory epithelium supported four main insights into the mechanism of hair cell regeneration. First, the results of $S$ phase labeling are consistent with the hypothesis that the supporting cells are the progenitor source of mitotic activity that eventually leads to morphologic recovery. Second, the differential increase in $\mathrm{S}$ phase label density in damaged end organs compared to controls indicates that the upregulation of proliferative activity observed after ototoxic damage is due to a large extent to an increase in numbers of dividing cells. Third, the mismatch between the distribution of proliferative activity and epithclial ototoxic damage suggests a generalized stimulus, such as a soluble chemical factor, as the trigger for mitotic activity. Finally, the distribution of $S, G 2$, and $M$ phase labeled cells within the epithelium suggests that proliferating cells in both the normal and regenerating sensory epithelium undergo intermitotic nuclear migration from an initial basal epithelial location to the lumenal surface during the early stages of the cell cycle; DNA synthesis is initiated while nuclei are in a basal position and mitosis occurs lumenally.

\section{Technical considerations}

PCNA ICC labeling of $S$ phase cells

A strong correlation between ${ }^{3} \mathrm{H}$-thymidine AR and PCNA immunolabeling has been well documented in vertebrate tissue (Galand and Degraef, 1989; Monaghan et al., 1991). This remains true in the chick inner ear. Both labels were seen in equivalent nuclear layers, groupings, and topographic distribution in the sensory epithelium and underlying stroma. The PCNA immunolabel linear density was greater than the corresponding values found with the $1 \mathrm{hr}$ pulse-fix protocol using ${ }^{3} \mathrm{H}$-thymidine in all organs. This correlates with the immunodetectable presence of PCNA in late $\mathrm{G} 1, \mathrm{~S}$, and early $\mathrm{G} 2$ phases 


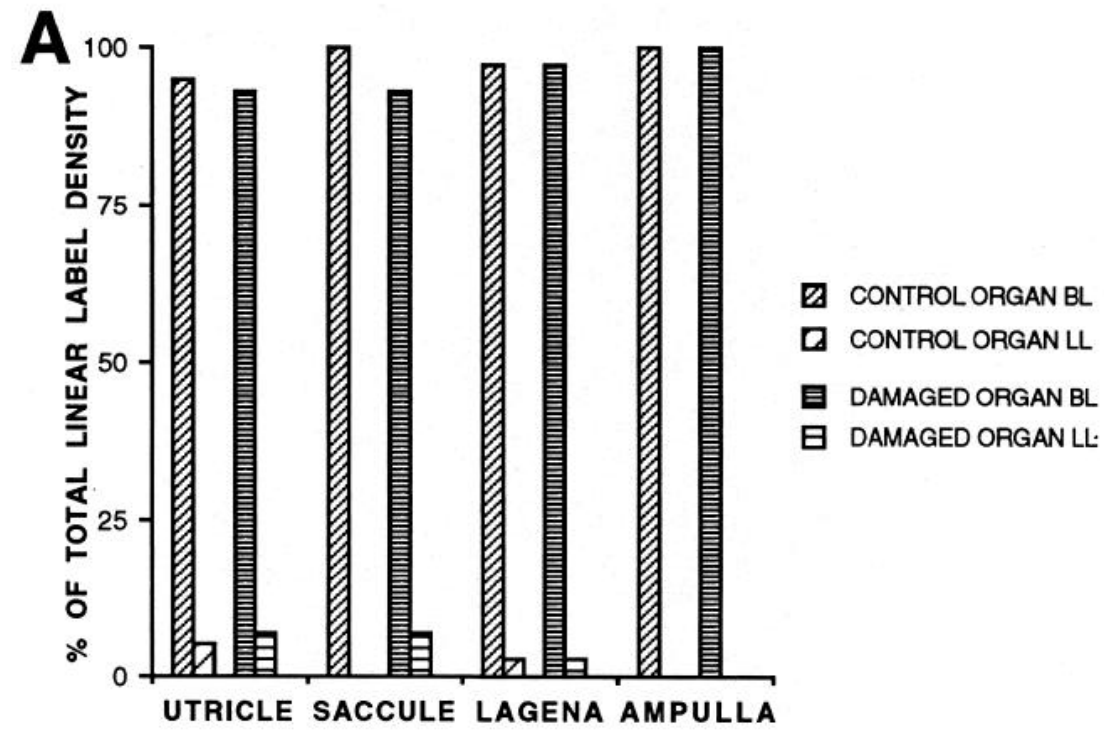

Figure 6. Percentage of total tritiated thymidine label linear density in the BL and LL sensory epithelial layers $1 \mathrm{hr}$ $(A)$ and $3 \mathrm{hr}(B)$ after tritiated thymidine injection. Percentages for both control and streptomycin-damaged vestibular organs are shown. Note the uniform decrease in the percentage of total labeled cells in the BL with longer survival time.

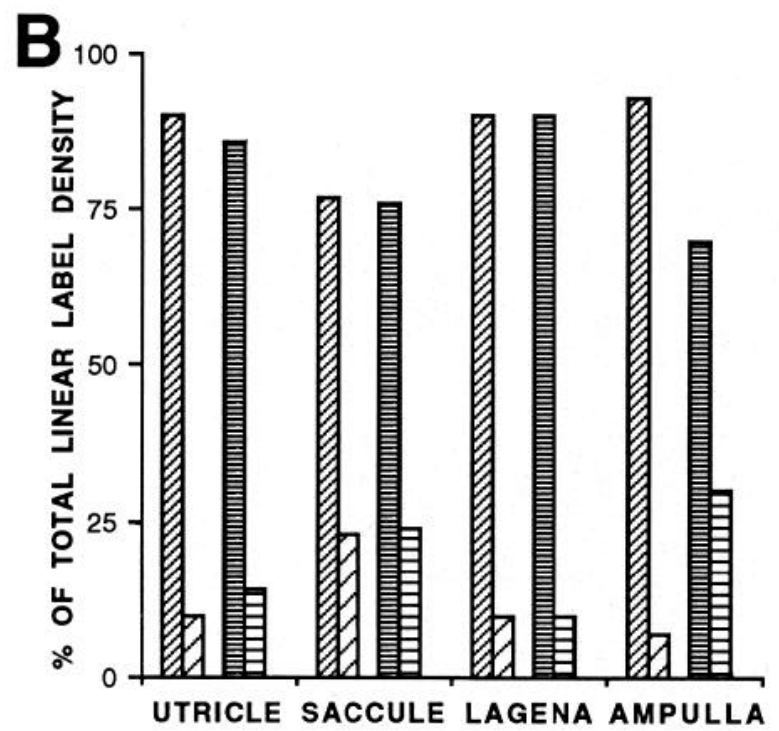

(Kurki et al., 1986) compared to incorporation of ${ }^{3} \mathrm{H}$-thymidine only during $\mathrm{S}$ phase. These results confirm the usefulness of PCNA ICC as a peri-S phase marker in the chick inner ear.

Using an ICC marker to detect proliferation has many advantages. Not only is the PCNA immunolabeling protocol fast, but detection of an endogenous antigen avoids use of potentially toxic agents, such as ${ }^{3} \mathrm{H}$-thymidine or 5-bromo-2'-deoxyuridine (BrdU). Tritiated thymidine can block proliferation (Blenkinsopp, 1967) and BrdU can impair cellular differentiation (Tapscott et al., 1989). The primary disadvantage of PCNA immunolabeling is the decreased histological resolution from dehydrative fixation and paraffin embedding.

\section{AR labeling of $S$ phase cells}

Unlike PCNA, ${ }^{3} \mathrm{H}$-thymidine remains in the cell nucleus after DNA replication, becoming permanently integrated into the nucleic acid structure. In the present study, a 1 and $3 \mathrm{hr}$ pulsefix protocol was used to label cells undergoing $\mathrm{S}$ phase. Developing chicken neural tissue shows G2 phase durations of 1-4 $\mathrm{hr}$ and $\mathrm{M}$ phase durations of 24-70 min (Fujita, 1962; Jacobsen, 1991). Grosset and Odartchenko (1975) demonstrated a G2 and
$\mathrm{M}$ phase duration of 1.05 and $0.5 \mathrm{hr}$, respectively, in the adult chicken erythroblast. Thus, cells that incorporated enough ${ }^{3} \mathrm{H}-$ thymidine during $\mathbf{S}$ phase and underwent complete mitosis, resulting in labeled progeny, would be uncommon. In fact, given the 4-8 $\mathrm{hr}$ duration of S phase in neural tissues of the developing chick (Fujita, 1962; Jacobsen, 1991) and the $6.9 \mathrm{hr}$ duration of $\mathrm{S}$ phase in the adult chicken erythroblast (Grosset and Odartchenko, 1975), most of the ${ }^{3} \mathrm{H}$-thymidine-labeled cells were most likely still in $\mathrm{S}$ phase.

\section{Hair cell progenitors in the vestibular sensory epithelium}

Four potential cellular sources of new hair cells are possible. First, a new hair cell could result from the transdifferentiation of another cell type without proliferation. Supporting cells are the most likely candidate, because of physical proximity and lack of other cell types within the sensory epithelium. However, transdifferentiation alone would lead to a decrease in the supporting cell population as the hair cell population increased. This contradicts what has been observed in previous long-term survival studies (Roberson et al., 1992; Weisleder and Rubel, 1993). New hair cells were labeled by proliferation markers and, 

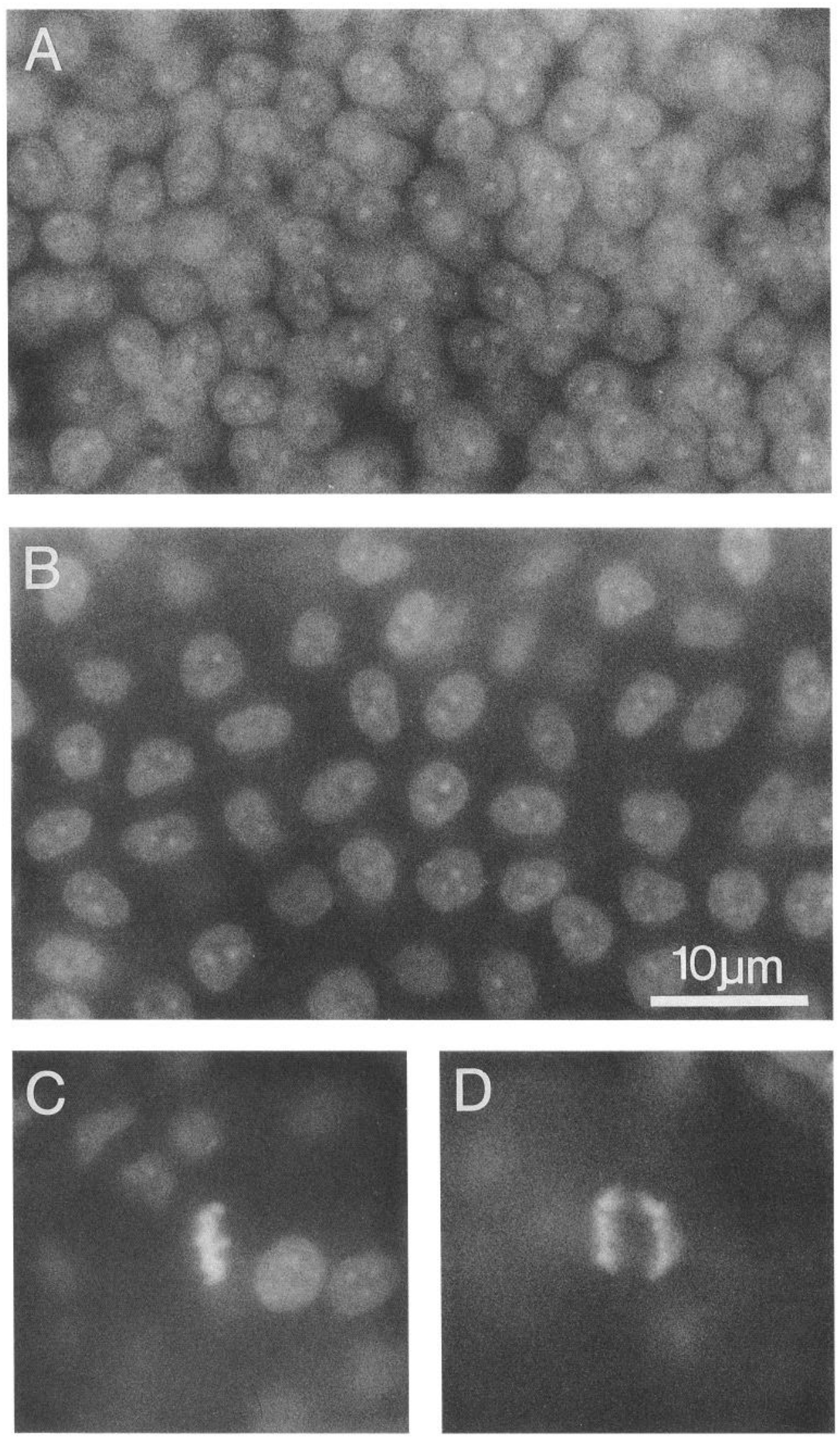

Figure 7. En face views of a chick utricle whole-mount stained with bisbenzimide after $5 \mathrm{~d}$ of streptomycin treatment. Focal planes of the tightly packed supporting cell nuclear layer $(A)$ and the more lumenal, more sparsely packed hair cell nuclear layer $(B)$ are shown. A metaphase mitotic figure $(C)$ is shown at or slightly lumenal to the hair cell nuclear layer, while an anaphase mitotic figure $(D)$ is shown near the lumenal surface. Note that the spindle axis is tangential and the cellular cleavage plane is perpendicular to the lumenal surface. The scale bar in $B$ applies to all panels. 


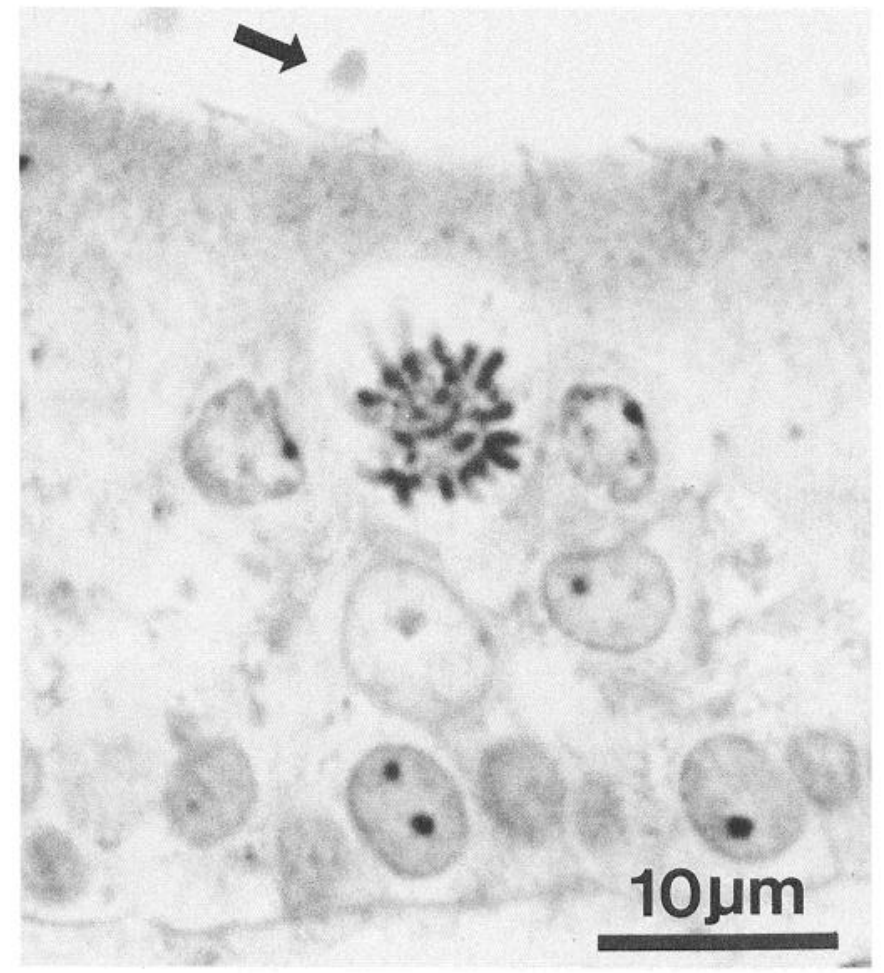

Figure 8. Photomicrograph showing condensed chromosomes of a mitotic figure near the lumenal sensory epithelium of a streptomycindamaged saccule. Arrow points to a hair cell stereociliary bundle on the lumenal epithelial surface.

in regenerating tissue, while the hair cell population density reached supranormal levels, the supporting cell population remained qualitatively unchanged. Second, an extraepithelial progenitor cell source is possible. Labeled stromal cells are uncommon, frequently distant from the sensory epithelium, and do not show an upregulation response to ototoxic damage, making this hypothesis unlikely. Third, hair cells themselves could proliferate to repopulate the epithelium. This hypothesis is also unlikely for several reasons. Labeled hair cells were not observed during the short survival periods employed in the present study. In vitro labeled hair cells are not seen until 2-3 d after streptomycin damage (Oesterle et al., in press), and Weisleder and Rubel (1993) did not observe labeled type I hair cells in vivo until $20 \mathrm{~d}$ after damage. The remaining and most plausible hypothesis is that intraepithelial precursor cells proliferate to produce new hair cells. In both normal and damaged vestibular end organs, the main focus of proliferative activity is located in the BL supporting cells. Labeled cells in the LL all morphologically resembled supporting cells; no labeled hair cells were seen. Weisleder and Rubel (1993) and Oesterle et al. (in press) also found supporting cell proliferation to be dominant. Roberson et al. (1992) showed a statistical pairwise association between proliferating supporting cells and a regenerated hair cell in control tissue. This evidence strongly suggests that supporting cell proliferation is integral to the cascade of events yielding a new vestibular hair cell. This appears to be true in both control and regenerating vestibular organs.

While no morphologic distinction could be made between labeled and unlabeled supporting cells using light microscopy, it is possible that only a subpopulation of supporting cells act as progenitors (Presson and Popper, 1990). Ultrastructural and ICC studies may help resolve this question.

\section{Ongoing and upregulated proliferation in the vestibular epithelium}

PCNA immunolabeling is useful for determining numbers of cells in the cell cycle at a given time, since an endogenous antigen intimately associated with DNA replication is detected. As first described by Jørgensen and Mathiesen (1988), we observe a low rate of ongoing proliferative activity in the normal vestibular sensory epithelium. The control lagena had the highest density of immunodetected proliferating cells, followed by the ampulla, utricle, and saccule. After pharmacologic insult, an increase in total immunolabel density was observed in each organ type. This upregulation of proliferative activity after damage has been observed both in vivo and in vitro in long-term survival studies (Weisleder and Rubel, 1993; Oesterle et al., in press). Because of the possible inclusion of multiple generations of ${ }^{3} \mathrm{H}$-thymidine-labeled progeny in these studies, the exact mechanism responsible for the increase in proliferative activity could not be previously discerned. However, PCNA immunolabeling allows us to conclude that an increase in the number of dividing cells contributes significantly to the mechanism of upregulation observed after aminoglycoside damage. Decreases in the duration of cell-cycle phases may also contribute to the upregulation of ${ }^{3} \mathrm{H}$-thymidine-labeled and PCNA-labeled nuclei observed after ototoxic damage, but such rate changes cannot be addressed with techniques used in this study.

In contrast to control tissue, the damaged saccule had the highest density of labeled nuclei, followed by the damaged utricle, lagena, and ampulla. This ranking was almost the exact reverse of that observed in controls, suggesting that those organs with higher ongoing proliferation may be less capable in upregulating reparative proliferation in response to injury.

\section{Hair cell regeneration trigger signal}

The regenerative postembryonic production of hair cells is induced by multiple forms of insult to the sensory epithelium, including aminoglycoside poisoning. In damaged mammal and fish vestibular organs, the aminoglycoside toxic effect has been localized to the striolar regions, where type I hair cells predominate (Lindeman, 1969; Yan et al., 1989). In the present study, the analogous regions in the chick vestibular epithelium were similarly damaged. However, reparative proliferation appeared to be relatively evenly distributed across the epithelial surface area regardless of the distribution of local damage. This pattern differs from that reported for some other vertebrate sensory epithelia that have distinct peripheral "growth zones," where the majority of proliferative activity is observed (Corwin, 1981, 1985). In addition, the amount of upregulated mitotic activity after insult does not appear to be directly related to the extent of damage. Lindeman (1969) and Igarashi et al. (1966) showed that the ampullae are more susceptible to the ototoxic effects of streptomycin than the maculae. Weisleder and Rubel (1993) confirmed this in the chick vestibular system. On the other hand, our results indicate that the maculae have a greater reparative response to damage than the crista ampullae in terms of number of cells entering the cell cycle, despite the lesser damage sustained from the aminoglycoside. These two observations of mismatches between extent of damage and proliferative response suggest that a more generalized stimulus, possibly a diffusible factor, may play a role in triggering hair cell regeneration as 
opposed to a localized mechanical injury stimulus suggested by others (Corwin and Warchol, 1991; Corwin et al., 1991). Undamaged zones would have less of a change in epithelial mechanical infrastructure, but can be easily penetrated by soluble chemical factors.

\section{Intermitotic migration of progenitor cell nuclei}

Although the majority of proliferative activity in the regenerating end organ is located basally in the epithelium, a significant amount is located lumenally. Only two explanations can yield this distribution: the labeled BL and LL cells represent separate proliferating populations or the labeled BL nuclei migrate in a lumenal direction into the LL. If separate proliferating populations existed, the percentage of total ${ }^{3} \mathrm{H}$-thymidine label in each layer, BL and LL, would theoretically remain the same for each organ type in both the 1 and $3 \mathrm{hr}$ survival groups. This would be true even if the hypothetically distinct prolifcrating BL and LL cell populations had different cell-cycle durations. For example, if this were the case, the $1 \mathrm{hr}$ survival group may have $x$ and $y{ }^{3} \mathrm{H}$-thymidine-labeled nuclei in the BL and LL, respectively. Then, in the $3 \mathrm{hr}$ survival group, $3 x$ and $3 y$ nuclei would be labeled in the BL and LL, respectively. Thus, in both survival groups, the percentage of total label in the BL and LL should be unchanged. However, as illustrated in Figure 6, after $3 \mathrm{hr}$ of survival, there is a consistent increase in the percentage of labeled nuclei in the LL compared to tissue from the $1 \mathrm{hr}$ survival group. Alternatively, the migration of proliferating basally located nuclei into the LL could explain this relative increase in ${ }^{3} \mathrm{H}$-thymidine-labeled nuclei in the LL. Labeled basal nuclei would subtract from the BL population density and concurrently add to the LL population density as the labeled nuclei moved from the basement membrane to the lumenal surface. This was observed in both control and damaged inner ears. Also, the percentage of total PCNA-immunolabeled cells found in the LL was higher than that observed with ${ }^{3} \mathrm{H}$-thymidine labeling. This is also consistent with intermitotic migration, since PCNA ICC is detecting the population of $\mathrm{G} 2$ phase cells that have already begun to migrate lumenally. This argument is further supported by the observation that all sensory epithelial mitoses were observed only at or near the lumenal surface in both normal and regenerating chick vestibular maculae.

Raphael (1992) also observed supporting cell mitotic figures near the lumenal surface in the regenerating chick basilar papilla. Intraepithelial nuclear migration has been observed in the developing chick neural tube (Sauer, 1935; Jacobsen, 1991) and in the developing inner ear (Ruben et al., 1971; Katayama and Corwin, 1993). Presson and Popper (1990) identified migrating hair cell and supporting cell precursor cells, called "embryoniclike neuroepithelial cells," in the fish statoacoustic end organ. Thus, after initiation of DNA replication and $S$ phase at the basement membrane, where they can be labeled by both AR and PCNA ICC techniques, proliferating supporting cell nuclei migrate lumenally and enter the PCNA immunodetectable G2 phase. The nuclei then reach the lumenal surface during mitosis where they can be visualized by bisbenzimide staining (Fig. 9). Our observations suggest that this pattern occurs during both ongoing and regenerating proliferation in the vestibular epithelium. Whether the daughter cells maintain their basement membrane and/or lumenal connections during $\mathbf{M}$ phase requires ultrastructural investigation, but the maintenance of a tangential spindle apparatus axis with perpendicular cleavage plane leaves open the possibility of maintaining cellular contact with both

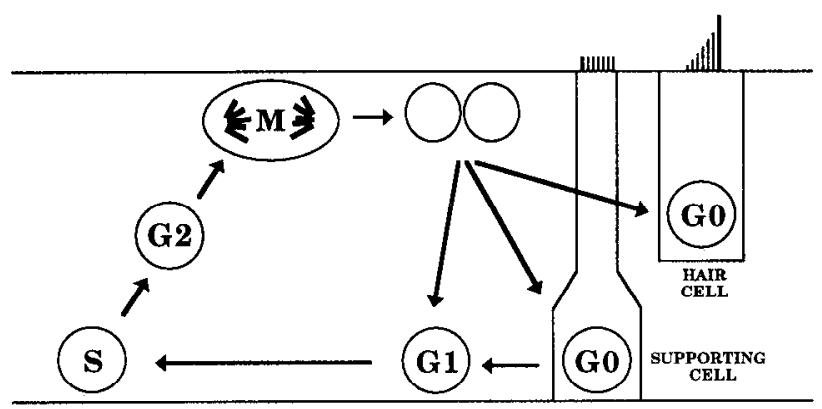

Figure 9. Schematic of intermitotic migration of precursor supporting cell nuclei in the normal and regenerating vestibular sensory epithelium (adapted from Corwin et al., 1991). Progenitor cell nuclei inhabit the basal layers of the epithelium. After entering the cell cycle, the nuclei migrate lumenally as $S$ phase progresses to $G 2$ phase. The nuclei reach the lumenal surface during $M$ phase and divide near the lumen. The daughter cells can then migrate basally to differentiate as hair celis or supporting cells, or continue in the cell cycle to produce more progeny. Alphanumeric labels refer to the cell-cycle phase of the migrating nuclei.

of these surfaces during and after mitosis. This is important since the resultant differentiated cell nuclear targets are located more basally in the epithelium and subsequent downward nuclear migration must occur after mitosis. Following mitosis, the final level of daughter cell nuclei is determined by or may determine the specific differentiated cell type (hair cell or supporting cell) that the progenitor cell will become. Besides final differentiation into hair cells, some progeny must return to the BL to maintain the supporting cell population. Daughter cells can theoretically also continue in the cell cycle (Stone and Cotanche, in press) and repeat the migration through the depth of epithelium to produce further progeny.

\section{References}

Balak KJ, Corwin JT, Jones JE (1990) Regenerated hair cells can originate from supporting cell progeny: evidence from phototoxicity and laser ablation experiments in the lateral line system. $J$ Neurosci 10:2502-2512.

Blenkinsopp WK (1967) Effect of tritiated thymidine on cell proliferation. J Cell Sci 2:305-308.

Bravo R, Macdonald-Bravo H (1987) Existence of two populations of cyclin/proliferating cell nuclear antigen during the cell cycle: association with DNA replication sites. J Cell Biol 105:1549-1554.

Bruno S, Crissman HA, Bauer KD, Darzynkiewicz Z (1991) Changes in cell nuclei during $S$ phase: progressive chromatin condensation and altered expression of the proliferation-associated nuclear proteins $\mathrm{Ki}$ 67, Cyclin (PCNA), p105, and p34. Exp Cell Res 196:99-106.

Celis JE, Madsen P, Celis A, Nielsen HV, Gesser B (1987) Cyclin (PCNA, auxiliary protein of DNA polymerase delta) is a central component of the pathway(s) leading to DNA replication and cell division. FEBS Lett 220:1-7.

Corwin JT (1981) Postembryonic production and aging of inner ear hair cells in sharks. J Comp Neurol 201:541-553.

Corwin JT (1983) Postembryonic growth of the macula neglecta auditory detector in the ray, Raja clavata: continual increases in hair cell number, neural convergence, and physiological sensitivity. J Comp Neurol 217:345-356.

Corwin JT (1985) Perpetual production of hair cells and maturational changes in hair cell ultrastructure accompany postembryonic growth in an amphibian ear. Proc Natl Acad Sci USA 82:3911-3915.

Corwin JT, Cotanche DA (1988) Regeneration of sensory hair cells after acoustic trauma. Science 240:1772-1774.

Corwin JT, Warchol ME (1991) Auditory hair cells: structure, function, development, and regeneration. Annu Rev Neurosci 14:301333.

Corwin IT, Iones IE, Katayama A, Kelley MW, Warchol ME (1991) Hair cell regeneration: the identities of progenitor cells, potential triggers and instructive cues. In: Ciba Foundation symposium 160, Re- 
generation of vertebrate sensory receptor cells (Rubel EW, ed), pp 103-130. Chichester: Wiley.

Cotanche DA (1987) Regeneration of hair cell stereociliary bundles in the chick cochlea following severe acoustic trauma. Hear Res 30 : 181-195.

Cruz RM, Lambert PR, Rubel EW (1987) Light microscopic evidence of hair cell regeneration after gentamicin toxicity in chick cochlea. Arch Otolaryngol Head Neck Surg 113:1058-1062.

Duckert LG, Rubel EW (1990) Ultrastructural observations on regenerating hair cells in the chick basilar papilla. Hear Res 48:161182.

Duckert LG, Rubel EW (1993) Morphological correlates of functional recovery in the chicken inner ear after gentamycin treatment. J Comp Neurol 331:75-96.

Duvall AJ, Wersäll J (1964) Site of action of streptomycin upon inner ear sensory cells. Acta Otolaryngol (Stockh) 57:581-598.

Fujita S (1962) Kinetics of cellular proliferation. Exp Cell Res 28:5260.

Galand P, Degraef C (1989) Cyclin/PCNA immunostaining as an alternative to tritiated thymidine pulse labelling for marking $S$ phase cells in paraffin sections from animal and human tissues. Cell Tissue Kinet 22:383-392.

Garcia RL, Coltrera MD, Gown AM (1989) Analysis of proliferative grade using anti-PCNA/cyclin monoclonal antibodies in fixed, embedded tissues: comparison with flow cytometric analysis. Am J Pathol 134:733-739.

Girod DA, Duckert LG, Rubel EW (1989) Possible precursors of regenerated hair cells in the avian cochlea following acoustic trauma. Hear Res 42:175-194.

Grosset L, Odartchenko N (1975) Duration of mitosis and separate mitotic phases compared to nuclear DNA content in erythroblasts of four vertebrates. Cell Tissue Kinet 8:91-96.

Igarashi M, McLeod ME, Graybiel A (1966) Clinical pathological correlations in squirrel monkeys after suppression of semicircular canal function by streptomycin sulfate. Acta Otolaryngol (Stockh) [Suppl] 214:1-28.

Jacobsen M (1991) Developmental neurobiology. New York, NY: Plenum.

Jørgensen JM (1981) On a possible hair cell turn-over in the inner ear of the caccilian Ichthyophis glutinosus (Amphibia: Gymnophiona). Acta Zool (Stockh) 62(3):171-186.

Jorgensen JM, Christensen JT (1989) The inner ear of the common Rhea (Rhea americana L.). Brain Behav Evol 34:273-280.

Jørgensen JM, Mathiesen C (1988) The avian inner ear: continuous production of hair cells in vestibular sensory organs, but not in the auditory papilla. Naturwissenschaften 75:319-320.

Katayama A, Corwin JT (1993) Cochlear cytogenesis visualized through pulse labeling of chick embryos in culture. J Comp Neurol 333:2840

Kurki P, Vanderlaan M, Dolbeare F, Gray J, Tan EM (1986) Expression of proliferating cell nuclear antigen (PCNA)/cyclin during the cell cycle. Exp Cell Res 166:209-219.

Lee S, Hurwitz J (1990) Mechanism of elongation of primed DNA by DNA polymerase delta, proliferating cell nuclear antigen, and activator 1. Proc Natl Acad Sci USA 87:5672-5676.

Lindeman HH (1969) Regional differences in sensitivity of the vestibular sensory epithelia to olotoxic antibiotics. Acta Otolaryngol (Stockh) 67:177-189.

Lippe WR, Westbrook EW, Ryals BM (1991) Hair cell regeneration in the chicken cochlea following aminoglycoside toxicity. Hear Res 56:203-210.

McFadden EA, Saunders JC (1989) Recovery of auditory function following intense sound exposure in the neonatal chick. Hear Res 41: 205-216.

Monaghan P, Perusinghe NP, Nicholson RI, McClelland RA, O'Hare MJ, Lane DP, Jayatilake H, Gusterson BA (1991) Growth factor stimulation of proliferating cell nuclear antigen (PCNA) in human breast epithelium in organ culture. Cell Biol Int Rep 15:561-570.

Oesterle EC, Rubel EW (1993) Postnatal production of supporting cells in the chick cochlea. Hear Res 66:213-224.

Oesterle EC, Tsue TT, Reh TA, Rubel EW (1993) Hair-cell regeneration in organ cultures of the postnatal chicken inner ear. Hear Res, in press.
Ogata K, Kurki P, Celis JE, Nakamura RM, Tan EM (1987) Monoclonal antibodies to a nuclear protein (PCNA/cyclin) associated with DNA replication. Exp Cell Res 168:475-486.

Popper AN, Hoxter B (1984) Growth of a fish ear: 1. Quantitative analysis of hair cell and ganglion cell proliferation. Hear Res 15:133142.

Popper AN, Hoxter B (1990) Growth of a fish ear: II. Locations of newly proliferated sensory hair cells in the saccular epithelium of Astronotus ocellatus. Hcar Res 45:33-40.

Prelich G, Stillman B (1988) Coordinated leading and lagging strand synthesis during SV40 DNA replication in vitro requires PCNA. Cell $53: 117-126$

Prelich G, Tan C, Kostura M, Mathews MB, So AG, Downey KM, Stillman B (1987) Functional identity of proliferating cell nuclear antigen and a DNA polymerase-delta auxiliary protein. Nature 326 517-520.

Presson JC, Popper AN (1990) Possible precursors to new hair cells, support cells, and Schwann cells in the ear of a post-embryonic fish. Hear Res 46:9-22.

Ramprashad F, Landolt JP, Money KE, Laufer J (1986) Comparative morphometric study of the vestibular system of the vertebrata: reptilia, aves, amphibia, and pisces. Acta Otolaryngol (Stockh) [Suppl] 427:1-42

Raphael Y (1992) Evidence for supporting cell mitosis in response to acoustic trauma in the avian inner ear. J Neurocytol 21:663-671.

Raska I, Koberna K, Jarnik M, Petrasovicova V, Bednar J, Raska K Jr, Bravo R (1989) Ultrastructural immunolocalization of cyclin/ PCNA in synchronized 3T3 cells. Exp Cell Res 184:81-89.

Retzius G (1884) Das Gehörorgan der Wirbelthiere. II: Das Gehörorgan der Reptilien, der Vögel und der Säugethiere. Stockholm: Samson und Wallin.

Roberson DF, Weisleder P, Bohrer PS, Rubel EW (1992) Ongoing production of sensory cells in the vestibular epithelium of the chick. Hear Res 57:166-174.

Ruben RJ (1967) Development of the inner ear of the mouse: a radioautographic study of terminal mitoses. Acta Otolaryngol (Stockh) [Suppl] 220:1-44.

Ruben RJ, van de Water T, Polesky A (1971) Cell kinetics of the 11 and 12-day mouse otocysts. Laryngoscope 10:1708-1718.

Ryals BM, Rubel EW (1988) Hair cell regeneration after acoustic trauma in adult Coturnix quail. Science 240:1774-1776.

Ryals BM, Westbrook EW (1990) Hair cell regeneration in the senescent quail. Hear Res 50:87-96.

Sauer FC (1935) Mitosis in the neural tube. J Comp Neurol 62:377405.

Shapiro HM (1989) Flow cytometry of DNA content and other indicators of proliferative activity. Arch Pathol Lab Med 113:591-597.

Stone IS, Cotanche DA (1993) Identification of the timing of S phase and the patterns of cell proliferation during hair cell regeneration in the chick cochlea. J Comp Neurol, in press.

Tapscott SJ, Lassar AB, Davis RL, Weintraub H (1989) 5-Bromo-2'deoxyuridine blocks myogenesis by extinguishing expression of MyoDl. Science 245:532-536.

Tucci DL, Rubel EW (1990) Physiologic status of regenerated hair cells in the avian inner ear following aminoglycoside ototoxicity. Otolaryngol Head Neck Surg 103:443-450.

Weisleder P, Rubel EW (1992) Hair cell regeneration in the avian vestibular epithelium. Exp Neurol 115:2-6.

Weisleder P, Rubel EW (1993) Hair cell regeneration after streptomycin toxicity in the avian vestibular epithelium. J Comp Neurol 331:97-110.

Wersäll J (1956) Studies on the structure and innervation of the sensory epithelium of the cristae ampullares in the guinea pig: a light and electron microscopic investigation. Acta Otolaryngol (Stockh) [Suppl] $126: 1-85$

Wersäll J, Hawkins JE (1962) The vestibular sensory epithelia in the cat labyrinth and their reactions in chronic streptomycin intoxication. Acta Otolaryngol (Stockh) 54:1-23.

Yan HY, Saidel WM, Chang JS, Presson JC, Popper AN (1989) Sensory hair cells of a fish ear: evidence of multiple types based on ototoxicity sensitivity. Proc R Soc London [Biol] 245:133-138. 